\title{
Urgensi Talak Di Depan Sidang Pengadilan Perspektif Maslahah Mursalah
}

\author{
Musda Asmara \\ Institut Agama Islam Negeri (IAIN) Curup \\ muгdasyubada@gmail.com \\ Reti Andira \\ Institut Agama Islam Negeri (IAIN) Curup \\ andira.reti@gmail.com
}

\begin{abstract}
Abstrak
Tulisan ini bertujuan untuk menemukan urgensi talak yang mesti dijatuhkan di depan sidang pengadilan sebagaimana yang di atur dalam pasal 115 Kompilasi Hukum Islam berdasarkan tinjauan maslabab mursalah. Hal ini dilakukan karena terdapat kontroversi ketentuan talak dalam fikih klasik dengan ketentuan talak yang terdapat dalam Undang-undang Perkawinan di Indonesia. Data yang disajikan dalam tulisan ini bersumber dari literatur kepustakaan. Adapun hasil dari tulisan ini menunjukkan bahwa tinjauan Maslabah mursalah terhadap penjatuhan talak yang mesti dilakukan di depan sidang pengadilan adalah agar perceraian yang terjadi mempunyai kepastian hukum baik untuk suami maupun istri bila hendak menikah lagi, selain itu untuk menjamin kepastian nafkah anak dan nafkah iddah bagi istri, dan istri bisa menuntut hak untuk pembagian harta gono gini. Selain itu, Pengadilan Agama merupakan salah satu institusi yang dapat mempersempit perceraian dan sekaligus dapat menggugurkan kebiasaan-kebiasaan penggunaan talak yang seenaknya
\end{abstract}

Kata kunci: Urgensi talak, sidang pengadilan, maslabah mursalah

\begin{abstract}
This paper aims to find the urgency of the divorce that must be imposed in front of the court as stipulated in article 115 Compilation of Islamic Law based on the review of maslahah mursalah. This was done because there was a controversy about the talak provisions in classical fiqh with the provisions of the divorce contained in the Marriage Law in Indonesia. The data presented in this paper are sourced from the literature. The results of this paper indicate that the review of Maslahah Mursalah against the imposition of divorce which must be done in front of the court is that the divorce has legal certainty for both husband and wife if they are to remarry, in addition to guaranteeing the child's livelihood and living for his wife, and the wife can claim the right to share property
\end{abstract}

Al Istinbath : Jurnal Hukum Islam vol. 3, no. 2, 2018

IAIN Curup-Bengkulu | p-issn: 2548-3374; e-issn: 2548-3382

Available online at : http://journal.staincurup.ac.id/index.php/alistinbath 
without this. In addition, the Religious Court is one of the institutions that can narrow divorce and at the same time can abort talak habits that are arbitrary.

Keywords: Urgency of divorce, court, maslahah mursalah

\section{Pendahuluan}

Islam membenarkan putusnya perkawinan sebagai langkah terakhir dari usaha melanjutkan rumah tangga setelah tidak ada lagi ditemukan jalan keluar atau solusi untuk melanjutkan bahtera rumah tangga. Dalam fikih klasik, Jumhur ulama berpendapat bahwa hak talak mutlak pada suami, oleh sebab itu kapan saja dan dimana saja seorang suami ingin menjatuhkan talak terhadap istrinya, baik ada saksi atau tidak, baik ada alasan atau tidak, talak yang dijatuhkan itu sah. Bahkan sebagian ulama mengatakan bahwa talak seorang suami yang dijatuhkan dalam keadaan mabuk pun dihukum sah.

Hal ini jauh berbeda dengan yang dimaksud oleh pasal 115 Kompilasi Hukum Islam (KHI), dalam pasal tersebut diatur bahwa "perceraian hanya dapat dilakukan di depan sidang pengadilan agama setelah pengadilan agama tersebut berusaha dan tidak berhasil mendamaikan kedua belah pihak,", bunyi pasal ini sangat bertolak belakang dengan konsep fikih klasik, dimana ketika seorang suami menjatuhkan talak kepada istrinya, maka talak itu sudah jatuh dan sah baik di ucapkan secara sindiran maupun secara langsung. Perbedaan prosedur penjatuhan talak yang terdapat dalam fikih klasik dengan Kompilasi Hukum Islam tentu menimbulkan kontroversi khususnya di kalangan masyarakat, jika kontroversi itu ada tentunya akan sangat berpengaruh terhadap efektifitas dalam penerapan hukum Islam berdasarkan Undang-Undang dan Kompilasi Hukum Islam di Indonesia.

Bunyi pasal 115 Kompilasi Hukum Islam tersebut tentu mempunyai maslahah atau tujuan tertentu, oleh sebab itu menarik kiranya untuk mengkaji lebih dalam bagaimana tinjauan maslahab mursalah terhadap pentingnya penjatuhan talak oleh suami terhadap istrinya di depan sidang Pengadilan.

${ }^{1}$ M. Anshary, Hukum Perkawinan di Indonesia, (Yogyakarta: Pustaka Belajar, 2010,) hal. 75

${ }^{2}$ Abdurahman, Kompilasi Hukum Islam di Indonesia, (Jakarta: Akademika Pressindo,2010), hal. 141 


\section{Pembahasan}

Talak menurut bahasa artinya "mengungkai" (melepaskan ikatan). Menurut hukum Islam mengungkai (melepaskan) ikatan perkawinan dan mengakhiri hubungan suami istri, ${ }^{3}$ talak juga berarti:

$$
\text { حل قيد النكا ح آو حل عقد النكا ح بلفظ الطلاق ونهوه }
$$

"Melepaskan kaitan (ikatan) perkawinan dengan lafaz, talak atau seumpamanya".

Berdasarkan beberapa defenisi yang tersebut di atas, maka jelaslah bahwa talak ialah pemutusan hubungan perkawinan antara suami dan istri, dengan mempergunakan lafal talak atau yang sama maksudnya dengan itu.

Dasar Hukum Talak

Adapun landasan hukum talak berdasarkan Alquran, hadis dan ijmak ulama, dalam Alquran terdapat dalam surat Al-Baqarah ayat 229:

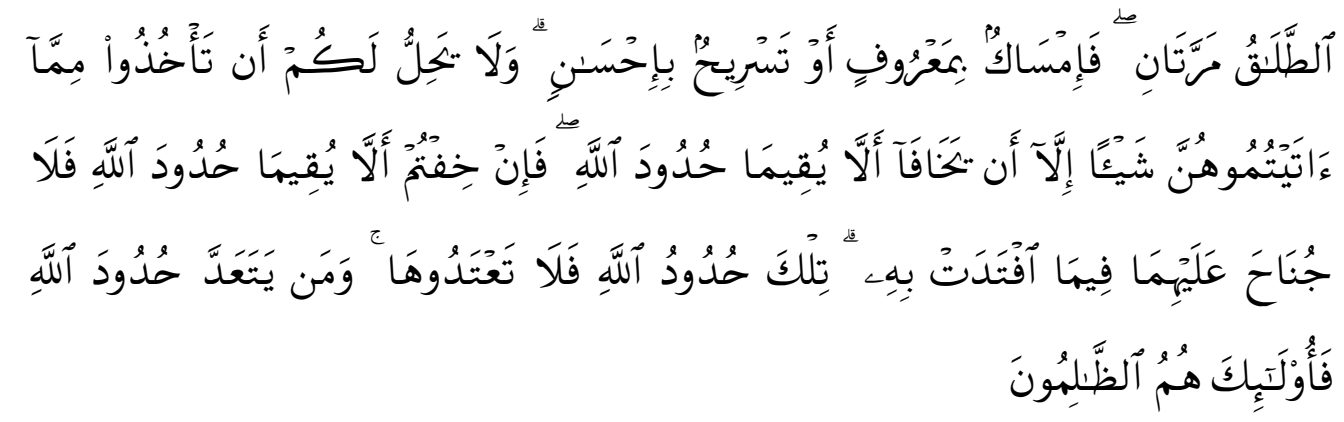

Talake (yang dapat dirujuki) dua kali. setelah itu boleh rujuk. lagi dengan cara yang ma'ruf atau menceraikan dengan cara yang baik. tidak, halal bagi kamu mengambil kembali sesuatu dari yang telab kamu berikan kepada mereka, kecuali kalau keduanya khawatir tidak. akan dapat menjalankan bukum-bukum Allah. jika kamu khawatir bahwa keduanya (suami isteri) tidak dapat menjalankan bukum-bukum Allah, Maka tidak ada dosa atas keduanya tentang bayaran yang diberikan oleh isteri untuk. menebus dirinya[144]. Itulah bukum-hukum Allah, Maka janganlah kamu melanggarnya. Barangsiapa yang melanggar bukum-bukum Allah mereka Itulah orang-orang yang zalim.

${ }^{3}$ Syaikh Hasan Ayyub, Fikih Keluarga Alih Bahasa M. Abdul Ghoffar, (Jakarta: Pustaka al-Kautsar, 2001), hal. 208

${ }^{4}$ Wahbah Al-Zahaili, Al-Fiqh Al-Islam wa Adillatubu, (Beirut: Al-Fikr, 1984), hal.356 
Surat An-Nisa ayat 35:

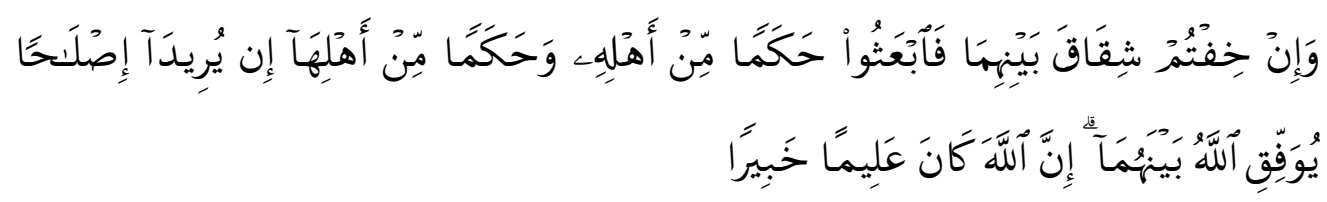

dan jika kamu khawatirkan ada persengketaan antara keduanya, Maka kirimlah seorang hakam dari keluarga laki-laki dan seorang hakam dari keluarga perempuan. jika kedua orang hakam itu bermaksud Mengadakan perbaikan, niscaya Allab memberi taufik kepada suami-isteri itu. Sesunggubnya Allah Maha mengetahui lagi Maha Mengenal.

Sedangkan dasar hukum talak berdasarkan hadis Nabi:

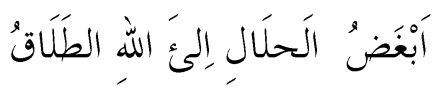

"Perkara halal yang paling dibenci oleh Allah adalah talak" (HR. Abu Daud dan AlHakim dari Ibnu Umar).

Manusia telah berkonsensus atas pembolehan talak, dan hal itu juga didukung oleh logika. Bisa saja kondisi hubungan antara suami istri telah rusak, sehingga dipeliharanya ikatan suami istri hanya semata-mata menjadi sebuah kerusakan dan keburukan, dengan dibebankannya suami untuk memberi nafkah dan tempat tinggal. Sementara istri ditahan dengan perlakuan yang buruk serta pertikaian yang bersifat terus menerus yang tidak ada faedahnya. Oleh karena itu, ditetapkannya hukum yang dapat melepaskan ikatan perkawinan untuk menghilangkan kerusakan dari sebuah perkawinan. ${ }^{6}$

Sighat Talak (kata-kata yang digunakan dalam menjatuhkan talak)

1. Hendaklah mentalak mereka dengan masa yang dapat diperhitungkan

Mentalak istri hendaknya dilakukan pada saat sudah dapat diperhitungkan masa iddahnya. Dengan demikian waktu menjatuhkan talak terhadap istri yang masih mengalami menstruasi adalah pada saat ia dalam keadaan suci dan belum digauli sebelumnya. Dengan demikian jika suami mentalak istrinya dalam keadaan suci, tetapi dikumpuli sebelumnya, atau istri dalam keadaan menstruasi berarti telah menyalahi aturan Alquran. Ketentuan mengenai talak yang dijatuhkan pada saat istri sedang menstruasi sama halnya dengan istri yang sudah dicampuri sebelumnya ${ }^{7}$.

\footnotetext{
${ }^{5}$ Hadis Riwayat Abu Dawud dan Ibnu Majah dengan sanad yang shahih, dan al-Hakim, dan dishahihkan hadis ini. Dati Ibnu Umar dalam kitab Nailul Authar.

${ }^{6}$ Wahbah Al-Zahaili, Al-Figh Al-Islam wa Adillatuhu, terj. (Jakarta: Gema Insani, 2011), hal.319

${ }^{7}$ Ahmad Azhar Basyir, Hukum Perkawinan Islam, (Yogyakarta: UII Press, 2000), hal.78
} 
2. Ungkapan talak dengan jelas (sharib)

Talak terjadi dengan segala sesuatu yang menujukkan putusnya perkawinan, baik menggunakan ucapan, tulisan yang ditujukan kepada istri, isyarat seorang suami yang bisu atau dengan utusan. Jika seorang berniat mentalak istrinya di dalam hati tanpa diungkapkan atau semacamnya maka tidak terjadi talak menurut orang-orang berilmu. Ucapan talak ada dua macam yaitu syarih (jelas) dan kinayah (sindiran). Talak syarib menggunakan tiga lafal yaitu (cerai) talak (pisah) firaq dan (terlepas) sarah. Lafal pertama sudah populer baik secara bahasa atau istilah sedangkan lafal kedua dan ketiga terdapat dalam Alquran dengan makna lafal terpisah antara suami dan istri $^{8}$.

3. Talak dengan sindiran

lafal talak dengan sindiran yaitu suatu kalimat yang mempunyai arti cerai atau yang lain. Kalimatnya banyak dan tak terhitung jumlahnya. Ungkapan kata yang tidak berarti talak, tidak menyerupainya, dan tidak menunjukkan cerai seperti perkataan seorang kepada istrinya, misalnya duduklah engkau cantik, semoga Allah memberkahi engkau, dan sesamanya. Dengan menggunakan kata-kata tersebut, tidak terjadi talak sekalipun berniat talak, karena kata-kata tersebut tidak ada kaitannya di dalam makna talak jika di jatuhkan juga talak hanya niat belaka. Berikut ini contoh talak dengan sindiran misalnya, engkau bebas, engkau terputus, engkau terpisah, melanggarlah, bebaskan rahimmu, pulang ke orangtua mu, pergilah dan masih banyak yang lain. ${ }^{9}$

4. Talak dengan tulisan

Talak dapat terjadi dengan tulisan walaupun penulis mampu berkata-kata. Sebagaimana suami boleh mentalak istri dengan lafal atau ucapan juga boleh mentalak dengan tulisan. Fuqahak mensyariatkan tulisan itu hendaklah jelas maksudnya dan jelas tulisannya sehingga terbaca ketika ditulis di lembaran kertas dan sesamanya. Contohnya "hai fulanah engkau terceraikan, tulisan tersebut termasuk sah dan jelas, maka terjadilah talak ${ }^{10}$.

\section{Persaksian dalam Talak}

Menurut jumhur fuqabak baik salaf maupun khalaf menjatuhkan talak tidak perlu saksi, karena talak itu sebagian dari hak suami maka tidak perlu bukti

${ }^{8}$ Abdul Aziz Muhammad, Azzam dan Abdul Wahab Sayyad Hawwas, Fiqih Munakahat, (Jakarta : Imprin Bumi Aksara, 2009), Hal 268

${ }^{9}$ Ibid, Hal. 269-270

${ }^{10} \mathrm{Ibid}$, Hal. 272-276 
atau saksi untuk melaksanakan haknya. Talak adalah hak suami, Allah jadikannya ditangan suami, dan Allah tidak jadikan hak kepada orang lain, sebagaimana firman Allah sebagai berikut:

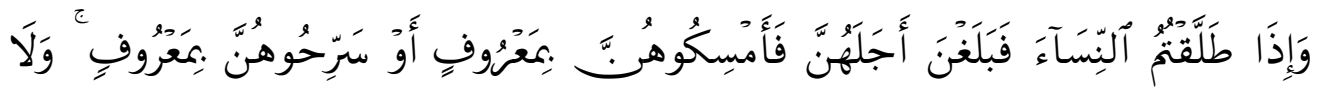

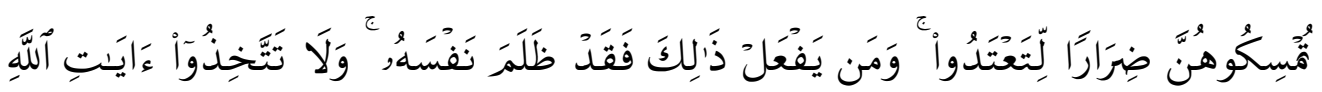

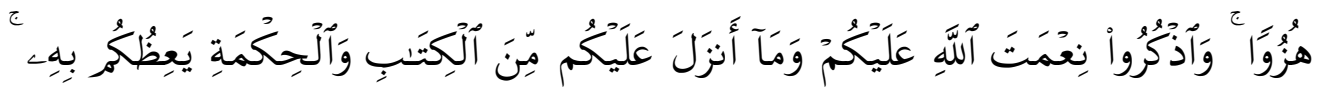

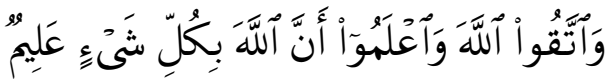

apabila kamu mentalak isteri-isterimu, lalu mereka mendekati akbir iddabnya, Maka rujukilah mereka dengan cara yang ma'ruf, atau ceraikanlab mereka dengan cara yang ma'ruf (pula). janganlah kamu rujuki mereka untuk memberi kemudharatan, karena dengan demikian kamu Menganiaya mereka ${ }^{11}$. Barangsiapa berbuat demikian, Maka sungguh ia telah berbuat zalim terhadap dirinya sendiri. janganlah kamu jadikan bukumbukum Allah permainan, dan ingatlah nikmat Allah padamu, dan apa yang telah diturunkan Allah kepadamu Yaitu Al kitab dan Al Hikmah (As Sunnah). Allah memberi pengajaran kepadamu dengan apa yang diturunkan-Nya itu. dan bertakwalah kepada Allah serta ketahuilah bahwasanya Allah Maba mengetahui segala sesuatu. (AlBaqarah ayat 231).

Menurut Al-Qurthubi, dalam penjatuhan talak itu diwajibkan adanya saksi $^{12}$, sebagaimana firman Allah dalam surat ATh-Thalak ayat 2:

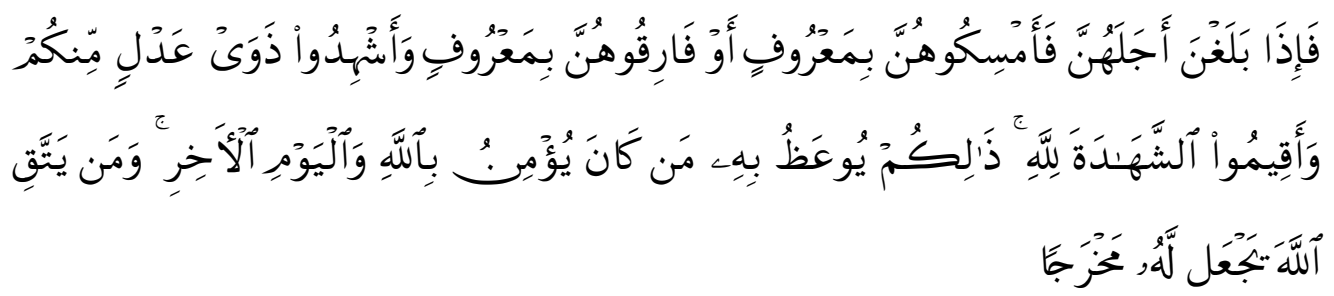

mereka telah mendekati akbir iddahnya, Maka rujukilab mereka dengan baik atau lepaskanlah mereka dengan baik dan persaksikanlah dengan dua orang saksi yang adil di antara kamu dan hendaklah kamu tegakekan kesaksian itu karena Allah. Demikianlah

11 Umpamanya: memaksa mereka minta cerai dengan cara khulu' atau membiarkan mereka hidup terkatung-katung.

12 Ahmad Azhar Basyir, op.cit., hal. 79 
diberi pengajaran dengan itu orang yang beriman kepada Allah dan hari akbirat. Barangsiapa bertakwa kepada Allah niscaya Dia akan Mengadakan baginya jalan keluar.

Perintah mempersaksikan dalam ayat tersebut menurut Al-Qurthubi, mancakup persaksian ketika merujuk dan memisahkan (mentalak). Diantara para sahabat yang berpendapat wajib adanya saksi dalam talak ialah Ali bib Abi Thaib dan Imran bin Husain. Diantara para thabi'in ialah Iman Muhammad Al-Baqir dan Imam Ja'far Shadiq (yang kemudian diikuti oleh ulama Syiah Imamiyah), Atha, Ibnu Juraij, Ibnu Sirin, dan ulama mazhab zahiri juga berpendapat demikian. $^{13}$

Apabila kita perhatikan dalil-dalil pendapat tentang wajibnya persaksian atas talak itu, dapat kita lihat bahwa pendapat tersebut mempunyai dasar yang cukup kuat, karena Islam mempunyai prinsip untuk mempersempit pintu perceraian. Dengan adanya ketentuan ini, suami yang akan menjatuhkan talak dengan disaksikan oleh dua orang laki-laki yang adil itu tidak akan diliputi suasana kebencian atau kemarahan terhadap istri yang ditalak, tetapi benar-benar atas pertimbangan yang matang sebelumnya bahwa langkah yang lebih baik adalah dengan menghentikan hubungan perkawinan sebab apabila dipertahankan juga tidak akan membawa kebaikan dalam perkawinan.

\section{Hak Perempuan yang di Talak}

Adapun hak-hak perempuan yang di talak oleh suaminya terbagi menjadi enam antara lain :

1. Islam memberikan syarat agar pelaksanaan talak pada waktu suci tidak terjadi setelah berkumpul dan perempuan tidak dalam masa haid, karena hal itu memberikan tenggang masa iddah bagi perempuan. Surah Ath-Talak ayat 1:

"Hai Nabi, apabila kamu menceraikan isteri-isterimu maka hendaklab kamu ceraikan mereka pada wak.tu mereka dapat (menghadapi) iddabnya (yang wajar) ${ }^{14}$ dan bitunglah waktu iddah itu serta bertakwalah kepada Allah Tubanmu. janganlah kamu keluarkan mereka dari rumah mereka dan janganlah mereka (diizinkan) ke luar kecuali mereka mengerjakan perbuatan keji yang terang ${ }^{15}$. Itulah bukum-hukum

${ }^{13}$ Ibid., hal 80

14 Maksudnya: isteri-isteri itu hendaklah ditalak diwaktu suci sebelum dicampuri. tentang masa iddah Lihat surat $\mathrm{Al}$ Baqarah ayat 228, 234 dan surat Ath Thalaaq ayat 4.

${ }^{15}$ Yang dimaksud dengan perbuatan keji di sini ialah mengerjakan perbuatan-perbuatan pidana, berkelakuan tidak sopan terhadap mertua, ipar, besan dan sebagainya. 
Allah, maka sesunggubnya dia telah berbuat zalim terbadap dirinya sendiri. kamu tidak mengetahui barangkali Allah mengadakan sesudah itu sesuatu bal yang baru.16"

2. Berbuat baik terhadap perempuan yang diceraikan dan berhubungan yang baik dengannya. Tidak ada pembalasan dendam dan penderitaan. Perpisahan dilakukan dengan tenang sebagaimana saat berkumpul keduanya dengan tenang.

3. Islam mewajibkan perempuan yang diceraikan dengan kecukupan harta untuk melindungi dari jiwa-jiwa yang dengki dan benci. Memberikan udara yang harum dengan penuh kehalusan dan kasih sayang. Allah berfirman dalam Surah Al-Baqarah ayat 241 :

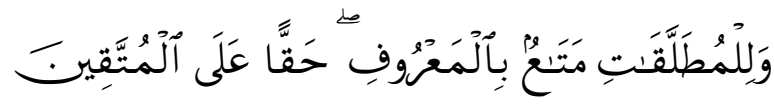

kepada wanita-wanita yang diceraikan (hendaklah diberikan oleh suaminya) mut'ab ${ }^{17}$ menurut yang ma'ruf, sebagai suatu kewajiban bagi orang-orang yang bertakwa.

4. Islam mengharuskan tetapnya perempuan yang dicerai selama masa iddah dalam rumah tangganya kecuali ia datang dengan huru hara dan membuat keburukan, maka boleh mengusirnya. Hikmhanya adalah kesenangan dalam penggerakan tersembunyi pada jiwa suami karena kecintaannya dan keinginannya bersama dengan istri. Terkadang ia menyiapkan jalan untuk menjernihkan berbagai pertentangan. Akan tetapi hal tersebut disyariatkan aman dari ketergelinciran pada perbuatan keji $1^{18}$.

5. Nafkah bagi perempuan yang diceraikan jika ia dalam keadaan hamil ialah sampai melahirkan. Hal tersebut sebagai wujud adanya hubungan antara ia dan suaminya, dengan adanya janin jika ia dalam keadaan hamil. Dan kekuasaan suami jika ingin kembali kepada istrinya jika tidak terjadi talak ba'in. Firman Allah dalam Surah Ath-Thalak ayat 6:

"Tempatkanlab mereka (para isteri) di mana kamu bertempat tinggal menurut kemampuanmu dan janganlah kamu menyusabkan mereka untuk menyempitkan (bati) mereka. dan jika mereka (isteri-isteri yang sudah ditalaq) itu sedang bamil, maka berikanlah kepada mereka nafkahnya hingga mereka bersalin, kemudian jika mereka menyusukan (anak-anak)mu maka berikanlah kepada mereka upabnya, dan

${ }^{16}$ Suatu hal yang baru Maksudnya ialah keinginan dari suami untuk rujuk kembali apabila talaqnya baru dijatuhkan sekali atau dua kali

17 Mut'ah (pemberian) ialah sesuatu yang diberikan oleh suami kepada isteri yang diceraikannya sebagai penghibur, selain nafkah sesuai dengan kemampuannya

${ }_{18}$ Ali Yusuf As-Subki, Fikib Keluarga: Pedoman Berkeluarga dalam Islam, (Jakarta: Amzah, 2010), hal. 343 
musyawarabkanlah di antara kamu (segala sesuatu) dengan baik; dan jika kamu menemui kesulitan maka perempuan lain boleh menyusukan (anak itu) untuknya."

6. Hak untuk kembali bagi suami dalam masa iddah, jika suami telah menceraikannya dengan sekali talak atau dua kali talak dengan tanpa perlu meminta izin dan kesaksian. Jika telah habis masa iddahnya maka perlu akad baru. Tidak ada orang yang dapat mencegahnya selagi mereka sepakat untuk kembali ${ }^{19}$.

\section{Al-Maslahah Al-Mursalah}

Sebelum menjelaskan arti Maslahah Al-mursalah, terlebih dahulu perlu dibahas tentang maslahah, karena maslabah mursalah itu merupakan salah satu bentuk dari maslahah. Dari segi bahasa, kata al-marsalah, adalah manfaat. Baik artinya maupun wujudnya, yang sama artinya dengan kalimat as-shalah, seperti halnya lafal al-naf' $u^{20}$.

Pengertian maslahah dalam bahasa Arab berarti perbuatan-perbuatan yang mendorong kepada kebaikan manusia. Dalam artinya yang umum adalah setiap segala sesuatu yang bermanfaat bagi manusia, baik dalam arti menarik atau menghasilkan seperti menghasilkan keuntungan atau kesenangan; atau dalam arti menolak atau menghindarkan seperti menolak kemudharatan atau kerusakan. Jadi setiap yang mengandung manfaat patut disebut maslahah dengan begitu maslabah mengandung dua sisi menarik atau mendatangkan kemaslahatan dan menolak atau menghindari kemudaratan ${ }^{21}$.

Dalam mengartikan maslahah secara definitif terdapat perbedaan rumusan di kalang ulama walaupun pada hakikatnya adalah sama.

1. Al-Ghazali menjelaskan bahwa pada asalnya maslahah itu berarti sesuatu yang mendatangkan manfaat (keuntungan) dan menjauhkan mudarat namun hakikat dari maslabah adalah :

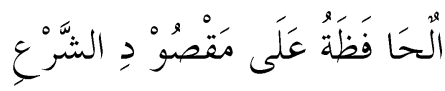

\section{Memelibara tujuan syara' (dalam mendapatkan bukum)}

Sedangkan tujuan syara' dalam menetapkan hukum itu ada lima, yaitu: memelihara agama, jiwa, akal keturunan dan harta ${ }^{22}$.

\footnotetext{
${ }^{19} \mathrm{Ibid}$, hal. 344

${ }^{20}$ Rahmat Syafe'i, Imu Ushul Fiqh, (Bandung : Pustaka Setia, 2000), hal. 117-119

${ }^{21} \mathrm{Ibid}$, hal.120

${ }^{22}$ Ibid, hal. 122
} 
2. Al-Khawarizmi memberikan definisi yang hampir sama dengan defenisi di atas yaitu :

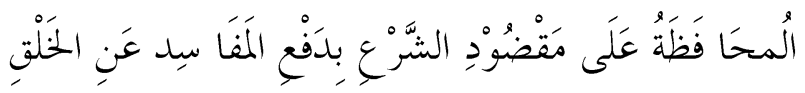

Memelibara tujuan syara' dalam menetapkan bukum dengan cara mengbindarkan kerusakan dari manusia.

Defenisi ini sama dengan defenisi di atas dari segi artinya dan tujuannya, karena menolak kerusakan itu mengandung arti menarik kemanfaatan, dan menolak kemaslahatan berarti menarik kerusakan ${ }^{23}$.

3. Al-Syatibi mengartikan maslahah itu dari dua pandangan, yaitu dari segi terjadinya maslabah dalam kenyataan dan dari segi tergantungnya tuntutantuntutan syara' kepada maslabah.

a. Dari segi terjadinya maslabah dalam kenyataan, berarti :

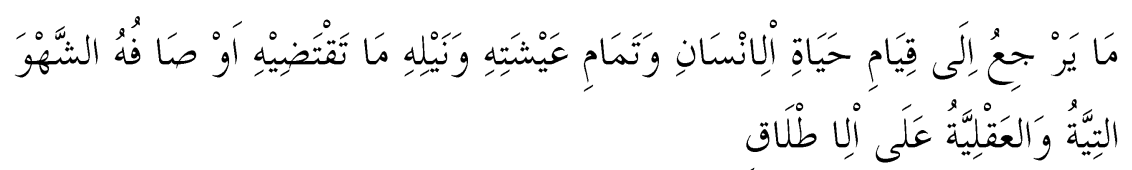

Sesuatu yang kembali kepada tegaknya kehidupan manusia, sempurna bidupnya, tercapai apa yang dikehendaki oleh sifat syahwati dan aklinya secara mutelak.

b. Dari segi tergantungnya tuntunan syara' kepada maslahah, yaitu kemaslahatan yang merupakan tujuan dari penetapan hukum syara' untuk menghasilkannya, Allah menuntut manusia untuk berbuat kebaikan $^{24}$.

Dari beberapa defenisi tentang maslahah di atas dengan rumusan yang berbeda tersebut dapat disimpulkan bahwa maslabah adalah sesuatu yang dipandang baik oleh akal sehat karena mendatangkan kebaikan dan menghindarkan keburukan (kerusakan) bagi manusia, sejalan dengan tujuan syara' dalam menetapkan hukum.

Dari kesimpulan tersebut terlihat adanya perbedaan antara maslahah dalam pengertian bahasa dan maslahah dalam pengertian hukum atau syara'. Perbedaannya terlihat dari segi tujuan syara' yang dijadikan rujukan. Maslahah dalam pengertian bahasa merujuk pada tujuan pemenuhan kebutuhan manusia dan karenanya mengandung pengertian untuk mengikuti syahwat atau hawa nafsu. Sedangkan maslahah dalam arti syara' yang menjadi titik bahasa dalam

${ }^{23}$ Ibid, hal. 123

${ }^{24}$ Ibid, hal. 124 
ushul fiqh, yang selalu menjadi ukuran dan rujukannya adalah tujuan syara' yaitu memelihara agama, jiwa, akal, keturunan dan harta benda, tanpa melepaskan tujuan pemenuhan kebutuhan manusia yaitu mendapatkan kesenangan dan menghindarkan ketidaksenangan ${ }^{25}$.

\section{Macam-Macam Maslabah}

Sebagaimana dijelaskan di atas bahwa maslahah dalam artinya syara' bukan hanya didasarkan pada pertimbangan akal dalam menilai baik buruknya sesuatu, bukan pula karena dapat mendatangkan kenikmatan dan menghindarkan kerusakan tapi lebih jauh dari itu, yaitu bahwa apa yang dianggap baik oleh akal juga harus sejalan dengan tujuan syara' dalam menetapkan hukum yaitu memelihara lima prinsip pokok kehidupan, umpamanya larangan minuman $\mathrm{keras}^{26}$. Adanya larangan ini menurut akal sehat mengandung kebaikan atau maslabah karena dapat menghindarkan diri dari kerusakan akal dan mental. Kekuatan maslahah dapat dilihat dari segi tujuan syara' dalam menetapkan hukum, yang berkaitan secara langsung atau tidak langsung dengan lima prinsip pokok kehidupan manusia, yaitu agama, jiwa, akal, keturunan, dan harta. Juga dapat dilihat dari segi tingkat, kebutuhan dari tuntutan kehidupan manusia kepada lima hal tersebut ${ }^{27}$.

1. Dari segi kekuatannya sebagai bujjah dalam menetapkan hukum, maslahah ada tiga macam, yaitu : maslahah dharruriyah, maslahah hajizyah dan maslahah tabsiniyah $^{28}$.

a. Maslahah dharuriyah adalah kemaslahatan yang keberadaannya sangat dibutukan oleh kehidupsn manusia, artinya kehidupan manusia tidak punya arti apa-apa bila satu saja dari prisip yang lima itu tidak ada. Segala usaha yang secara langsung menjamin atau menuju pada keberadan lima prinsip tersebut adalah baik atau maslahah dalam tingkat dharuri. Karena itu Allah memerintahkan manusia melakukan usaha bagi pemenuhan kebutuhan pokok tersebut. Meninggalkan dan menjahui larangan Allah tersebut adalah baik atau maslahah dalam tingkat dharuri. Dalam hal ini Allah melarang murtad untuk memelihara agama, melarang membunuh untuk memelihara jiwa, melarang minumminuman keras untuk memelihara akal, melarang berzina untuk

\footnotetext{
${ }^{25} \mathrm{Ibid}$, hal.124

${ }^{26}$ Satria Effendi dan Muhammad Zein, Ushul Fiqh, (Jakarta : Kencana, 2005), Hal. 148-

${ }^{27}$ Ibid, hal. 149

${ }^{28}$ Ibid, hal. 150
} 149 
memelihara keturunan, dan melarang mencuri untuk memelihara $\operatorname{harta}^{29}$.

b. Maslahah hajizah adalah kemaslahatan tingkat kebutuhan hidup manusia kepadanya tidak tidak mendapat tingkat dharuri. Bentuk kemaslahatanya tidak secara langsung bagi pemenuhan kebutuhan pokok yang lima, tetapi secara tidak menuju kearah sana seperti dalam hal yang memberi kemudahan bagi pemenuhan kebutuhan hidup manusia. Maslahah hajiyah juga jika tidak terpenuhi dalam kehidupan manusia, tidak sampai secara langsung menyebabkan rusaknya lima unsur pokok tersebut, tetapi secara tidak langsung memang bisa mengakibatkan perusakan. Contoh maslahah hajiyah adalah menurut ilmu agama untuk tegaknya agama, makan untuk kelangsungan hidup, mengasah otak untuk menyempurnakan akal, melakukan jual beli untuk mendapatkan harta. Semua itu merupakan perbuatan baik atau maslabah dalam tingkat haji.

c. Maslahah tahsiniyah adalah maslabah yang kebutuhan hidup manusia kepadanya tidak sampai tingkat dharuriyah, juga tidak sampai tigkat hajiiyyah namun kebutuhan tersebut perlu dipenuhi dalam rangka memberi kesempurnaan dan keindahan bagi hidup manusia. Misalnya, menggunakan pakaian yang bagus-bagus ketika shalat, memakai wangiwangian bagi laki-laki yang ingin berkumpul dengan orang banyak, mengharamkan makan makanan yang buruk atau menjijikan Maslahah dalam bentuk tahsini tersebut, juga berkaitan dengan lima kebutuhan pokok manusia ${ }^{30}$.

Tiga bentuk maslahah tersebut, secara beruntun menggambarkan tingkat kekuatannya, mulai dari yang paling kuat sampai yang paling lemah, perbedaan tingkat kekuatan ini harus didahulukan mana yang lebih penting dan akan terlihat bila terjadi pembenturan kepentingan antar sesamanya.

2. Dari adanya keserasian dan kesejalanan anggapan baik oleh akal itu dengan tujuan syara' dalam menetapkan hukum, ditinjau dari maksud usaha mencari dan menetapkan hukum, maslahah itu disebut juga dengan munasib atau keserasian maslahah dengan tujuan hukum. Maslahah dalam artian manasib itu dari segi pembuat hukum memperhatikannya atau tidak, maslahah terbagi kepada tiga macam, yaitu :

a. Maslahah al-mu'tabarab yaitu maslahah yang diperhitungkan oleh syar'i. Maksutnya adalah petunjuk dari syar'i baik langsung maupun tidak 
langsung yang memberikan penunjuk pada arah maslabah yang menjadi alasan dalam menetapkan hukum ${ }^{31}$. Dari langsung dan tidak langsung tersebut maslahah terbagi menjadi dua bagian yaitu :

1) Manasib mu'atstsir yaitu ada petunjuk langsung dari pembuatan hukum yang memperhatikan maslahah tersebut. Contohnya dalil nash yang menujukan langsung kepada maslahah umpamanya tidak baik mendekati perempuan yang sedang haid dengan alasan haid itu adalah penyakit. Hal ini dikatakan maslahah karena menjauhkan diri dari kerusakan atau penyakit. Contoh dalam ijma'menetapkan adanya kewalian ayah terhadap harta anak-anaknya dengan ilat belum dewasa $^{32}$.

2) Munasib mulaim yaitu tidak ada petunjuk langsung dari syara' baik dalam bentuk nash atau ijma' tentang perhatian syara' terhadap maslahah tersebut, namun secara tidak langsung ada. Contohnya :

a) Pelanjutan perwalian ayah terhadap anak gadisnya dengan alasan anak gadisnya yang belum dewasa. Ini alasan bagi hukum yang sejenisnya yaitu perwalian harta bagi anak kecil.

b) Boleh jama' bagi orang yang muqim karena hujan. Keadaan hujan itu memang tidak pernah dijadikan alasan untuk hukum jama' sholat namun syara' melalui ijma' menetapkan kedaan yang sejenisnya yaitu dalam perjalanan menjadi alasan bolehnya jama' dalam shalat ${ }^{33}$.

b. Maslahah al-mulghah atau maslahah yang di tolak, yaitu maslabah yang dianggap baik oleh akal, tetapi tidak diperhatikan oleh syara' dan ada petunjuk syara' yang menolaknya. Hal ini berarti syara', namun ternyata syara' menetapkan hukum, yaitu mencampuri istrinya di siang hari bulan Ramadhan. Untuk orang ini sanksi yang paling baik adalah disuruh puasa dua bulan berturut-turut, karena cara inilah yang diperkirakan akan membuatnya jera melakukan pelanggaran, pertimbangan ini memang baik dan masuk akal, bahkan sejalan dengan tujuan syara' dalam menetapkan hukum, yaitu menjerahkan orang dalam melakukan pelanggaran ${ }^{34}$. Namun apa yang dianggap baik oleh akal ini, ternyata tidak demikian menurut syar'i, bahkan ia menetapkan hukum yang

\section{Hal 116-117}

${ }^{31}$ Abdul Wahhab Khallaf, Ilmu Ushul Fiqh, terj, (Semarang : Toha Putra Grub 1974),

${ }^{32}$ Ibid, hal. 118

${ }^{33}$ Ibid, hal. 120

${ }^{34}$ Ibid, hal. 123 
berbeda dengan itu, yaitu harus memerdekakan hamba sahaya, meskipun sanksi ini bagi orang kaya atau raja dinilai kurang relevan untuk dapat membuat jera.

c. Maslahah al-mursalah atau juga disebut istilah yaitu yang dipandang baik oleh akal, sejalan dengan tujuan syara' dalam menetapkan hukum namun tidak ada petunjuk syara' yang memperhitungkannya dan tidak ada pula petunjuk syara' yang menolaknya. Jumhur ulama sepakat untuk menggunakan maslahah mu'tabarah sebagaimana juga sepakat menolak maslahah mulghah. Menggunakan metode maslahah al-mursalah dalam berijtihad ini menjadi perbincangan yang berkepanjangan di kalangan ulama ${ }^{35}$.

\section{Syarat-Syarat Berhujjah dengan Maslahah Mursalah}

Ulama yang berhujjah dengan maslahah mursalah berhati-hati untuk menjadikannya sebagai hujjah, sehingga dia tidak menjadi pintu bagi pembentukan hukum menurut hawa nafsu dan kesenangan. Oleh karena itu, mereka mensyaratkan tiga syarat pada maslabah yang menjadi dasar pembentukan hukum, yaitu :

1. Ia harus merupakan kemaslahatan yang hakiki, dan bukan suatu kemaslahatan yang bersifat dugaan saja, yang dimaksudkan dengan persyaratan ini ialah untuk membuktikan bahwa pembentukan hukum pada suatu kasus mendatangkan kemanfaatan dan menolak bahaya ${ }^{36}$. Adapun sekedar dugaan bahwa suatu pembentukan hukum menarik suatu manfaat, tanpa mempertimbangkannya dengan bahaya yang mendatang, maka ini adalah berdasarkan kemslahatan yang bersifat dengan maslahab wahmiyyah. Contohnya kemaslahatan yang berdasarkan dengan ini pencabutan hak suami untuk mentalak istrinya dan meletakkan hak penthalakan di tangan hakim saja dalam segala situasi dan kondisi ${ }^{37}$.

2. Bahwa ia adalah kemaslahatan umum, dan bukan kemaslahatan pribadi. Yang dimaksud dengan syarat ini ialah untuk membuktikan bahwa pembentukan hukum pada suatu kasus adalah mendatangkan manfaat bagi mayoritas ummat manusia, atau menolak bahaya dari mereka, dan bukan untuk kemaslahatan individu atau sejumlah persorangan yang merupakan minoritas dari mereka. Hukum tidaklah boleh disyariatkan untuk mewujudkan kemaslahatan khusus bagi penguasa atau pembesar, dan

\footnotetext{
${ }^{35}$ Ibid, hal. 124

${ }^{36}$ Ibid, hal. 327

${ }^{37}$ Ibid, hal. 328
} 
memalingkan pandangan dari mayoritas ummat dan kemaslahatan mayoritas ummat manusia ${ }^{38}$.

3. Bahwa pembentukan hukum berdasarkan kemaslahatan ini tidak bertentangan dengan hukum atau prinsip yang telah berdasarkan nash atau ijma'. Oleh karena itu, tidak sah mengakui kemaslahatan yang menuntut persamaan antara anak laki-laki dan anak perempuan dalam pembagian warisan, karena kemslahatan ini dibatalkan, karena ia bertentangan dengan nash Alquran. Dari uraian ini dijelaskan bahwasanya kemslahatan yang dengan kata lain: sifat yang munasib, apabila ada bukti syara' yang menujukan pengakuan terhadapnya, dengan salah satu dari bentuk pengakuan maka itulah sifat munasib. Adapun jika bukti syar'i menujukan pembatalan pengakuan tehadapnya, maka sifat itu adalah munasib al-mulgha atau yang dibatalkan dan apabila tidak ada bukti syar'i maupun pembatalannya, maka sifatnya adalah munasib mursal. Dengan kata lain disebut maslahah mursalah.

\section{Perbedaan Pendapat Ulama Mengenai Maslahah Mursalah}

Para ulama ushul fiqh sepakat bahwa maslaba mursalah tidak sah menjadi landasan hukum dalam bidang ibadah, karena bidang ibadah harus diamalkan sebagaimana adanya yang diwariskan oleh Rasullulah, dan oleh karena itu bidang ibadah tidak berkembang. Mereka berbeda pendapat dalam bidang muamalat. Kalangan Zahiriyah, sebagian dari kalang Syafi'iyah dan Hanafiyah tidak mengakui maslahah mursalah sebagai landasan pembentukan hukum, dengan alasan yang dikemukakan Abdul Karim Zaidan, antara lain ${ }^{39}$ :

1. Allah dan Rasulnya telah merumuskan ketentuan-ketentuan hukum yang menjamin segala bentuk kemaslahatan ummat manusia. Menetapkan hukum berlandaskan maslahah mursalah, berarti menganggap syariat Islam tidak lengkap karena menganggap masih ada maslahah yang belum tertampung oleh hukum-hukumnya. Hal yang seperti itu bertentangan dengan ayat 36 Surah Al-Qiyamah:

Apakah manusia mengira, bahwa ia akan dibiarkan begitu saja (tanpa pertanggungjawaban)

2. Membenarkan maslahah mursalah sebagai landasan hukum berarti membuka pintu bagi berbagai pihak seperti hakim dipengadilan atau pihak penguasa untuk menetapkan hukum menurut seleranya dengan alasan untuk meraih kemaslahatan. Praktik seperti itu jelas akan merusak agama.

\footnotetext{
${ }^{38} \mathrm{Ibid}$, hal. 329

${ }^{39}$ Khalaf, Op, Cit, hal. 121
} 
Dengan alasan-alasan tersebut mereka menolak maslahah mursalah sebagai landasan menetapkan hukum. Berbeda dengan itu, kalangan Malikiyah dan Hanabilah, serta sebagian dari kalangan Syafiiyah berpendapat bahwa maslahah mursalah secara sah dapat dijadikan landasan menetapkan hukum. Diantara alasan-alasan yang mereka ajukan adalah ${ }^{40}$ :

1. Syariat Islam diturunkan, seperti disimpulkan para ulama berdasarkan petunjuk-petunjuk Alquran dan Sunnah, bertujuan untuk merealisasikan kemaslahatan dan kebutuhan umat manusia. Kebutuhan ummat manusia itu selalu berkembang, yang tidak mungkin semuanya dirinci dalam Alquran dan Sunnah Rasullulah. Namun secara umum syariat Islam telah memberi petunjuk bahwa tujuannya adalah untuk memenuhi kebutuhan umat manusia. Oleh sebab itu, apa-apa yang dianggap maslahah, selama tidak bertentangan dengan Alquran dan Sunnah Rasulullah, sah dijadikan landasan hukum.

2. Para sahabat dalam berijtihad menganggap sah maslahah mursalah sebagai landasan hukum tanpa ada seorang pun yang membantahnya. Contohnya, Umar bin Khattab pernah menyita sebagian harta para pejabat di masanyay ang diperboleh dengan cara menyalagunakan jabatannya. Praktik ini tidak pernah dicontohkan oleh Rasulullah, akan tetapi hal itu perlu dilakukan demi menjaga harta negara dari rongrongan para pejabatnya.

Berdasarkan alasan-alasan tersebut dan beberapa alasan yang lain yang tidak dapat disebutkan semua dalam tulisan ini, kalangan Malikiyah, Hanabilah dan sebagian dari kalangan Syafiiyah menganggap sah maslahah mursalah sebagai landasan hukum ${ }^{41}$.

\section{Maslahah Talak yang Dilakukan di Depan Sidang Pengadilan}

Dalam Islam sudah dijelaskan untuk terjadinya perceraian harus memenuhi beberapa persyaratan. Antara lain: suami, istri, lafal talak, dan sengaja untuk menjatuhkan talak atau sengaja untuk bercerai. Memang dalam fiqh suami mempunyai hak yang luas untuk menjatuhkan talak, kapanpun dan dimanapun suami mengucapkannya talak itu jatuh seketika. Keadaan seperti ini dipandang dari sudut kepentingan keluarga, kepastian hukum dan ketertiban masyarakat, tidak mewujudkan kemaslahatan bahkan banyak merugikan kaum wanita. Di Negara Indonesia ini sangat jelas bahwa perkara perceraian merupakan perkara yang kewenangannya dimiliki oleh Pengadilan Agama maupun Pengadilan Negeri. Oleh karena itu demi kemaslahatan, maka perceraian harus di proses melalui Pengadilan Agama bagi yang beragama Islam. Di dalam UU No. 1 tahun

\footnotetext{
${ }^{40}$ Effendi Satria dan Muhammad Zain, Ushul Figh, (Jakarta: Kencana, 2010), hal 150

${ }^{41}$ Ibid, hal. 152
} 
1974 tentang perkawinan sudah menjelaskan talak harus dilakukan di depan Pengadilan Agama berdasarkan pasal 39 ayat 1 dan Kompilasi Hukum Islam pasal 115 yang berbunyi: perceraian hanya dapat dilakukan di depan sidang pengadilan setelah pengadilan berusaha dan tidak berhasil mendamaikan kedua belah pihak. Oleh karena itu tidak ada alasan untuk tidak mengikrarkan talak di depan pengadilan.

Maslahah adalah suatu yang dianggap baik, dan sejalan dengan tujuan syara' dalam menetapkan suatu hukum, jumhur ulama sepakat dalam menggunakan maslahah untuk berijtihad, jika apa yang menurut akal itu baik dan selaras pula dengan tujuan syara', serta tidak ada pula petunjuk syara' yang menolaknya dan maslahah tersebut berguna untuk kemaslahatan umat. Maka, maslabah tersebut bisa diterima oleh ulama-ulama fiqih di Indonesia. Mengingat akan pentingnya mengikararkan talak di depan pengadilan, merupakan maslahah yang baik, maka negara mengharuskan masyarakat untuk menjatuhkan talak di depan pengadilan agar tercapainya kemaslahatan hidup setelah terjadinya perceraian. Supaya para suami tidak asal-asalan saja dalam menjatuhkan talak kepada istrinya.

Adapun maslahah yang mengharuskan talak dilakukan di depan sidang Pengadilan Agama yaitu :

1. Mempunyai kepastian hukum.

Agar talak yang sudah dijatuhkan itu mempunyai kepastian hukum khususnya bagi istri, ketika istri mau menikah lagi, ia tidak akan kesulitan untuk mengurus proses nikahnya di Kantor Urusan Agama (KUA). Karena KUA tidak akan mengabulkan permohonan janda untuk menikah lagi tanpa ada surat keterangan resmi dari Pengadilan Agama bahwa ia sudah menjadi janda. Begitu juga dengan suami, sama halnya dengan istri, suami yang melakukan perceraian di luar Pengadilan akan mengalami kesulitan ketika hendak menikah lagi dengan perempuan lain. Perceraian yang dilakukan di luar pengadilan tidak akan memiliki surat cerai yang sah dan memiliki kekuatan hukum tetap, sehingga jika hendak menikah lagi melalui pihak KUA tidak akan diizinkan sampai ada surat yang sah dari Pengadilan Agama $^{42}$.

2. Adanya kepastian tentang nafkah anak.

Setelah suami dan istri bercerai, mereka berdua tetap mempunyai kewajiban memelihara dan mengasuh anak-anak, maka dalam hal ini Pengadilan dapat memberikan putusan bahwa sang suami tetap

\footnotetext{
${ }^{42}$ Hilman Hadi Kusuma, Hukum Perkawinan Indonesia menurut Perundang, Hukum Adat, Hukum Agama, (Bandung : Bandar Maju, 1990), hal. 20
} 
bertanggung jawab memberikan semua biaya pemeliharaan sampai pendidikan sesuai dengan kebutuhan anak, jika sang suami tidak mampu, sang istri bisa menggantikan kewajiban sang suami tersebut. Kalau talak dilakukan di luar Pengadilan, tentu anak tidak mendapatkan haknya, yaitu berupa nafkah, karena banyak sekali kasus setelah berpisah anak tidak mendapatkan haknya dan anak menjadi terbengkalai.

3. Kepastian tentang nafkah istri.

Kepastian nafkah istri yaitu nafkah iddah, tempat tinggal selama iddah, dan pembagian harta bersama. Seorang istri yang diceraikan di pengadilan bisa menuntut untuk nafkah selama istri menjalankan iddah dan ia juga bisa menuntut untuk pembagian harta bersama, harta yang di dapatkan selama hidup berumah tangga. Jika perceraian dilakukan di luar pengadilan istri tidak akan bisa menuntut haknya selama masa iddah dan juga tidak bisa menuntut tentang harta bersama atau harta yang mereka dapatkan selama pernikahan, karena tidak adanya bukti yang sah bahwa istri sudah menjadi janda.

Berdasarkan penjelasan di atas, mengikrarkan talak di depan sidang pengadilan merupakan keniscayaan agar kepentingan wanita dan anak-anak selaku kaum lemah tetap terlindungi. Dalam hal ini menjatuhkan talak di depan pengadilan bertujuan untuk mewujudkan kemaslahatan berupa perlindungan terhadap institusi keluarga dan perwujudan kepastian hukum dimana perkawinan tidak dengan mudah begitu saja diputuskan. Pemutusan perkawinan harus didasari dengan alasan-alasan yang jelas. Dengan demikian talak yang dilakukan di depan pengadilan berarti talak telah melalui pemeriksaan terhadap alasanalasannya melalui proses sidang Pengadilan.

Selain itu, al-Haddad mencatat sebagaimana dikemukakan oleh fatwa MUI ada beberapa alasan pentingnya penetapan ikarar talak di depan Pengadilan Agama yaitu:

1. Pengadilan merupakan lembaga kekuatan pelindung. Pengadilan yang berfungsi sebagai pelindung merupakan salah satu sarana kita untuk melindungi hak-hak sebagai seorang istri dan anak, dengan melakukan talak di depan pengadilan maka ada lembaga yang menjamin dan melindungi agar semua hak istri dan anak dapat dipenuhi oleh suami.

2. Pengadilan merupakan upaya penyelamatan keluarga dan perkawinan dari kehancuran. Di dalam pengadilan tidak langsung hakim memutuskan pasangan suami istri bercerai tetapi memiliki tahapan untuk memperbaiki rumah tangga seperti dilakukannya mediasi agar rumah tangga yang goyah bisa kembali utuh 
3. Pengadilan menjamin agar penggunaan talak tidak menyimpang dari ajaran Islam sehingga hak talak dilakukan benar-benar dalam keadaan darurat.

4. Pengadilan diharapkan dapat berperan dalam menjamin hak masing-masing pihak sebagai akibat perceraian. Pengadilan memiliki kekuatan hukum dalam menjamin hak seorang istri dan anak sehingga jika suami tidak memenuhi apa yang menjadi kewajibannya, maka istri dapat melapor dan menuntut haknya tersebut.

5. Pengadilan dapat menjamin ketentuan hidup para istri, lebih-lebih lagi bagi suami yang mempunyai istri lebih dari satu.

6. Pengadilan diharapkan dapat mencatat sebab-sebab terjadinya perceraian

7. Pengadilan diharapkan dapat berperan memberikan pelajaran kepada pihakpihak yang berperkara. ${ }^{43}$

\section{Penutup}

Undang-undang perkawinan di Indonesia telah mengatur bahwa perceraian hanya dapat dilakukan oleh seorang suami di depan sidang Pengadilan Agama setelah hakim terlebih berusaha mendamaikan kedua belah pihak dan tidak berhasil untuk didamaikan. Talak yang dilakukan di depan sidang pengadilan bertujuan untuk mewujudkan kemaslahatan agar perceraian tidak mudah begitu saja diputuskan, karena Islam mempunyai prinsip untuk mempersempit pintu perceraian. Pengadilan Agama merupakan salah satu institusi yang dapat mempersempit perceraian tersebut dan sekaligus dapat menggugurkan kebiasaan-kebiasaan penggunaan talak yang seenaknya. Selain itu maslahah talak yang dilakukan di depan Pengadilan Agama juga bertujuan untuk melindungi hak istri dan hak anak selaku kaum lemah.

${ }^{43}$ Ijtima' Ulama Komisi Fatwa se-Indonesia IV, Solusi Hukum Islam Terbadap Masalah Keumatan Dan Kebangsaan (Jakarta: MUI, 2012), hal. 179 


\section{Daftar Pustaka}

Anshary, M., Hukum Perkawinan di Indonesia, (Yogyakarta: Pustaka Belajar, 2010)

Abdurahman, Kompilasi Hukum Islam di Indonesia, (Jakarta: Akademika Pressindo, 2010)

Ayyub, Syaikh Hasan, Fikih Keluarga Alih Bahasa M. Abdul Ghoffar, Jakarta: Pustaka al-Kautsar, 2001)

Al-Zahaili, Wahbah, Al-Figh Al-Islam wa Adillatubu, (Beirut: Al-Fikr, 1984) -, Al-Figh Al-Islam wa Adillatuhu, terj. (Jakarta: Gema Insani, 2011)

Abdul Aziz Muhammad, Azzam dan Abdul Wahab Sayyad Hawwas, Fiqih Munakahat, (Jakarta : Imprin Bumi Aksara, 2009)

As-Subki, Ali Yusuf, Fikih Keluarga: Pedoman Berkeluarga dalam Islam, Jakarta: Amzah, 2010)

Basyir, Ahmad Azhar, Hukum Perkawinan Islam, (Yogyakarta: UII Press, 2000)

Ijtima' Ulama Komisi fatwa se-Indonesia iv, Solusi Hukum Islam Terbadap Masalah Keumatan Dan Kebangsaan (Jakarta: MUI, 2012)

Khallaf, Abdul Wahhab, Imu Usbul Fiqh, terj, (Semarang : Toha Putra Grub 1974)

Kusuma, Hilman Hadi, Hukum Perkawinan Indonesia menurut Perundang, Hukum Adat, Hukum Agama, (Bandung : Bandar Maju, 1990),

Syafe’i, Rahmat, Ilmu Ushul Figh, (Bandung : Pustaka Setia, 2000)

Satria, Effendi dan Muhammad Zein, Ushul Fiqh, (Jakarta : Kencana, 2010) 